\title{
REPRESENTASI STRATEGI KEKUASAAN SIMBOLIK TUTURAN GURU DALAM MEMBUKA PEMBELAJARAN
}

\author{
Siti Nur Afifatul Hikmah \\ e-mail: afifahikmah16@gmail.com \\ Prodi Tadris Bahasa Indonesia \\ IAI Darussalam Blokagung Banyuwangi
}

\begin{abstract}
Abstrak
Representasi sebagai gambaran wujud terhadap suatu hal. Dalam hal ini representasi guru dalam pembelajaran memiliki kekuasaan. Kekuasaan simbolik tuturan guru dalam pembelajaran menjadikan guru sebagai seseorang atau kelompok pemegang kuasa simbol. Kekuasaan simbolik yang dilakukan oleh guru dalam pembelajaran tidak terlepas dari tindak tutur yang berupa bentuk perintah, ajakan, nasehat, pujian, pertanyaan, penjelasan dan informasi. Metode penelitian ini menggunakan pendekatan kualitataif dengan jenis penelitian lapangan.
\end{abstract}

\section{Kata Kunci: strategi kekuasaan, tuturan guru, pembelajaran}

\begin{abstract}
Representation as a picture of the existence of a thing. In this case the representation of teachers in learning has power. The symbolic power of the teacher's speech in learning makes the teacher a person or group that holds the power of symbols. The symbolic power exercised by the teacher in learning cannot be separated from speech acts in the form of orders, invitations, advice, praise, questions, explanations and information. This research method uses a qualitative approach with the type of field research.
\end{abstract}

Keywords: power strategy, teacher's speech, learning

\section{A. Pendahuluan}

Strategi sebagai cara yang digunakan guru untuk membangun kegiatan belajar yang menyenangkan di dalam kelas. Strategi guru membangkitkan minat siswa dalam belajar dan motivasi siswa dalam belajar sebagai mekanisme dalam menjalankan strategi kekuasaan guru menstimulus siswa memberikan pengetahuan atau kelimuan melalui topik materi yang dipelajari. Strategi kekuasaan simbolik dalam membuka pembelajaran sebagai upaya yang dilakukan guru mengawali kegiatan belajar mengajar.

Kegiatan pembelajaran berjalan dengan optimal melalui serangkaian proses strategi yang ditempuh oleh guru diawal pembelajaran. Pada tahapan ini guru mengkondisikan kelas dan memberikan motivasi kepada siswa. Menurut Hikmah (2021:60) Pembelajaran akan tercapai secara maksimal dengan dukungan sarana dan prasarana pembelajaran yang memadai. pembelajaran yang baik mampu merumuskan 
tujuan dan pencapian kompetensi. Selain itu, guru juga mengajak siswa baik siap secara mental ataupun psikis. Dengan cara ini guru memberikan pengaruh posistif untuk mengawali proses pembelajaran misalnya (a) guru mengucapkan salam sebelum memulai kegiatan pembelajaran, (b) guru menanyakan kehadiran siswa dan mencatat siswa yang tidak hadir, (c) memberikan pertanyaan kepada siswa pembahasan materi sebelumnya, (d) mengajukan pertanyaan kepada siswa di kelas tentang materi yang sudah dipelajari sebelumnya sebagai tolak ukur penguasaan atau pemahaman materi, (e) memberikan kesempatan kepada siswa untuk bertanya tentang materi yang sekiranya belum dipahami atau dikuasai, dan (f) mengulang kembali bahan pelajaran yang sebelumnya secara singkat, padat, dan mencakup semua aspek materi yang sebelumnya.

Penggunaan strategi kekuasaan simbolik yang dilakukan guru dalam pembelajaran mempunyai tujuan untuk memaksimalkan proses pembelajaran siswa. Pada tahapan membuka atau prainstruksional guru mengungkapkan kembali tanggapan siswa terhadap materi yang diterima dan menumbuhkan kondisi belajar (Majid, 2016:28). Selain itu, guru menghubungkan materi yang akan dibahas sesuai dengan fenomena yang ada di lingkungan sekitar agar siswa mampu menyerap atau memahami materi yang akan dipelajari. Dalam kegiatan ini, guru memberikan stimulus kepada siswa agar siswa berhasil dalam belajar. Strategi kekuasaan simbolik guru dalam membuka pembelajaran meliputi (1) resiprokal, (2) hegemonial, dan (3) ekspansiaonal.

\section{B. Metode Penelitian}

Penelitian ini menggunakan pendekatan kualitatif. Pendekatan tersebut dipilih karena memiliki fokus menemukan pola hubungan terhadap realitas subjek berdasarkan data dilapangan secara lisan atau tulis. Pendekatan kualitatif menggunakan instrumen kunci yaitu peneliti dalam pengambilan data selama di lapangan. Penelitian kualitatif sebagai human instrumen, berfungsi menetapkan focus penelitian, memilih informan sebagai sumber data, melakukan pengumpulan data, menilai kualitas data, analisis data, menafsirkan data dan membuat kesimpulan atas temuannya (Ma'arif, 2021:162).

Menurut Bogdan dan Biklen (2003: 33-36) bahwa penelitian kualitatif memiliki karakteristik (1) penelitian ini menggunakan latar alamiah atau pada konteks suatu keutuhan yang berasal dari tindak ilokusi memuji guru perempuan kepada siswa di dalam kelas selama kegiatan pembelajaran bahasa Indonesia berlangsung, (2) penelitian ini bersifat deskriptif karena data penelitian ini berupa kata-kata atau kalimat dan bukan angka-angka, (3) penelitian ini disamping mengutamakan proses juga hasil atau produk, (4) analisis data bersifat deskriptif dan induktif, dan (5) makna dipandang sebagai sesuatu 
yang esensial, artinya hasil analisis data dan temuan penelitian bermakna dalam konteksnya.Peneliti ikut berpartisipasi selama proses di lapangan dengan mencatat hal-hal penting sebagai penunjang data, peneliti melakukan analisis reflektif, dan membuat laporan penelitian.

Jenis penelitian ini adalah penelitian lapangan. Penelitian lapangan ini mempelajari secara intensif tentang latar belakang keadaan, interaksi sosial, individu, kelompok, lembaga, dan masyarakat. Ancangan teoritis yang digunakan dalam penelitian ini adalah pragmatik. Penggunaan teoritis pragmatik dalam penelitian ini, Analisis tersebut bertujuan untuk menentukan maksud penutur, baik yang diekspresikan secara tersurat maupun tersirat melalui tuturan. Pragmatik sebagai cabang ilmu linguistik membahas tentang struktur bahasa sebagai alat komunikasi antara penutur dan mitra tutur dan sebagai pengacuan tanda-tanda bahasa pada hal-hal ekstralingual yang dibicarakan (Verhaar, 1996: 14).

\section{Hasil dan Pembehasan}

Pada penelitian ini dipaparkan hasil dan pembahasan yaitu representasi kekuasaan simbolik tuturan guru dalam pembelajaran.

1. Resiprokal

Resiprokal atau pembelajaran secara timbal balik sebagai strategi pembelajaran yang membangun siswa berpikir aktif, kreatif, dan kritis dalam proses pembelajaran. Strategi resiprokal yang dilakukan oleh guru pada saat membuka pembelajaran, supaya siswa mampu belajar secara berkelompok dan mengembangkan metakognitif. Guru sebagai fasilitator yang menjawab pertanyaan-pertanyaan yang diajukan oleh siswa. Hubungan timbal balik guru dengan siswa juga memberikan efek pada pembelajaran yaitu keaktifan dan motivasi belajar. Berikut strategi resiprokal guru dalam membuka pembelajaran.

\section{Kutipan (1)}

(Konteks: Tuturan tersebut terjadi di ruang kelas pada pagi hari. Guru memasuki ruang kelas dan beridiri dihadapan siswa mengucapkan salam. Siswa menjawab salam yang diucapkan oleh guru. Sebelum pembelajaran dimulai, guru menanyakan kabar kepada siswa yang dilanjutkan dengan mengupas materi yang sudah dipelajari sebelumnya)

G: "Assalamu'alaikum, selamat pagi anak-anak!"

S: "Wa'alaikumussalam bu. Selamat pagi."

G: "Bagaimana kabar kalian hari ini?" (guru sambil tersenyum dengan 
ekspresi penuh semangat)

S: "Baik, bu"

G: "Alhamdulillah baik anak-anak. Sebelum melanjutkan ke materi (guru selanjutnya ibu absen dulu. Dita azzahra, Annisatul fitria, Dito"

mengabsen siswa)

S: "Ada bu"

G: "Apakah hari ini ada yang tidak masuk?"

S: "Masuk semua bu."

(G.1/S.MB/RSP)

\section{Kutipan (2)}

(Konteks: Tuturan tersebut terjadi di ruang kelas pada siang hari. Guru (penutur) memasuki ruang kelas dan menyiapkan materi ajar. Guru kemudian mengucapkan salam kepada siswa, menanyakan kabar, dan memberikan ulasan pertanyaan tentang materi yang sudah dipelajari sebelumnya)

G: "Selamat pagi anak-anak?"

S: "Ucapkan salam. Assalamu'alaikum, wr.wb."

G: "Wa'alaikum salam wr.wb anak-anak. Bagaimana kabarnya hari ini?"

S: "Alhamdulillah allohu akbar."

G: "Terima kasih. Oke, sebelum ibu membahas materi hari ini, kita singgung sedikit materi kemarin. Tentang cerita fantasi."

S: "Iya, bu.

G: "Ayo, kamu Andi bisa diceritakan kembali cerita fantasi itu seprti apa?"

$\mathrm{S}$ : "Ya, bu. Cerita fantasi adalah cerita yang berbentuk angan-angan atau imajinasi."

G: "Iya, bahwa cerita fantasi merupakan sebuah cerita yang memiliki tokoh, setting, dan konflik yang tidak realis. Artinya, bahwa ceria fantasi itu berbentuk khayal dan hanya imajinasi saja."

(G.4/S.MB/RSP)

Pada kutipan (1) dan (2) merupakan strategi resiprokal yang dilakukan oleh guru saat membuka pembelajaran. Dalam strategi tersebut guru memberikan stimulus kepada siswa untuk semangat belajar.Hal ini guru memiliki kekuasaan dalam menggunakan bahasa sebagai alat kekuasaan simbolik dan menggunakan strategi demi tujuan belajar. Sejumlah pertanyaan yang diberikan oleh guru kepada siswa sebagai mekanisme guru dalam membangkitkan semangat belajar. Tujuan penggunaan strategi pada kutipan percakapan diatas merupakan timbal balik atau pergantian posisi yang dilakukan oleh guru kepada siswa pada saat pembelajaran.

Strategi resiprokal yang dilakukan oleh guru dalam pembelajaran memiliki peran penting dalam membimbing dan melancarkan siswa menguasai materi ajar. 
Peran tersebut tentunya melibatkan guru dalam interaksi kelas yaitu membantu dalam mentransformasikan kepercayaan, pengetahuan, pemahaman, keterampilan, dan komitmen kepada siswa. Refleksi dan keyakinan tentang praktik sosial dipandang sebagai cara untuk meningkatkan pemikiran dan pemecahan masalah. Dengan cara ini guru dapat mengajar secara profesional berinteraksi dengan siswa sehingga dapat mendorong partisipasi untuk lebih aktif dan tingkat keterlibatan kognitif yang lebih tinggi. Keterlibatan siswa dalam konstruksi pengetahuan yang dibimbing dapat menghasilkan keuntungan yang signifikan dalam pembelajaran (Alghasab,dkk. 2019:18). Dengan diskusi dan dialog siswa dapat membangunan pengetahuan, pemahaman, dan cenderung berpikir kritis terhadap topik atau ide yang diberikan oleh guru.

Strategi kekuasaan guru memberikan dampak positif terhadap proses pembelajaran siswa. Hal ini tentunya membutuhkan pengajaran yang didasarkan atas prinsip-pronsip pembelajaran. Alexander (2017a:28) menetapkan lima prinsip pengajaran dialogis yaitu a) kolektif: guru dan siswa membahas tugas belajar bersama baik sebagai kelompok atau individual, bukan secara terpisah, b) timbal balik: guru dan siswa saling mendengarkan, berbagi ide, dan mempertimbangkan sudut pandang alternatif, c) mendukung: siswa mengartikulasikan ide-ide secara bebas tanpa takut malu atas jawaban salah dan saling membantu mencapai pemahaman bersama, d) kumulatif: guru dan siswa membangun ide sendiri satu sama lain dan membentuk rantai ke dalam garis pemikiran yang koheren, serta e) bertujuan: guru merencanakan dan memfasilitasi pengajaran dialogis dengan tujuan pembelajaran. Dalam strategi pembelajaran tersebut memiliki tahapan yaitu membuka, inti, dan menutup. Tahapantahapan strategi tersebut memberikan kontribusi kepada siswa untuk memahami materi ajar dengan baik.

Strategi pembelajaran pada kurikulum 2013 siswa perlu dan harus terlibat mengkonstruksi pemahaman melalui penalaran oleh diri sendiri maupun dalam kelompok diskusi atau suatu kelompok kecil yang membahas suatu materi belajar. Guru lebih dominan bersifat sebagai fasilitator dalam proses membangun pengetahuan siswa. Pembelajaran yang berpusat pada siswa (student centred learning) harus memberi ruang bagi siswa untuk belajar menurut ketertarikannya, kemampuan pribadinya, dan gaya belajarnya. Siswa secara natural berbeda-beda satu dengan yang lainnya baik dalam ketertarikannya terhadap suatu bahan ajar, kemampuan intelektual masing-masing, maupun dalam gaya belajar yang disukainya. Lebih jauh lagi 
kemampuan intelektual dari masing-masing siswa berbeda-beda. Dengan demikian, guru harus pandai mengolah strategi pembelajaran yang menarik perhatian siswa, agar siswa dapat belajar sesuai dengan kebutuhan.

Strategi pembelajaran beriorientasi sebagai standar prosesyang memiliki unsur tersendiri yang dapat membedakan antara kegiatan belajar dengan yang bukan belajar. Unsur-unsur tersebut mencakup tujuan belajar, motivasi, hambatan, stimulus, persepsi, dan respon siswa terhadap proses belajar. Hal ini tampak jelas bahwa kehadiran guru dalam proses pembelajaran mutlak untuk dilakukan. Kegiatan pembelajaran sebagai proses dan hasil berlangsungnya fungsi pembelajaran (Majid, 2016:36). Dengan demikian, fungsi pembelajaran sebagai upaya mendorong, mengajak, memerintah, membimbing, dan melatih dalam memenuhi kebutuhan belajar.

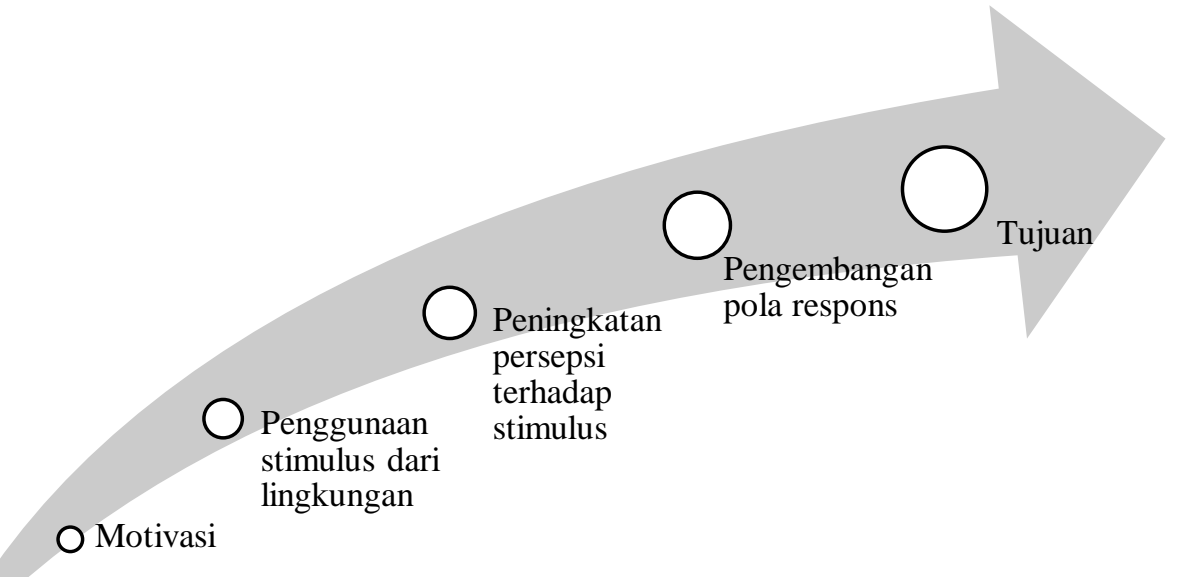

\section{Gambar 6.2 Gambaran umum langkah-langkah kegiatan pembelajaran yang dimodifikasi dari Majid (2016:36)}

Penggunaan strategi kekuasaan simbolik tuturan guru tampak pada saat guru memberikan motivasi kepada siswa sampai dengan tujuan pembelajaran. Dengan pendekatan dan proses belajar yang maksimal diharapkan dapat mengoptimalkan pembelajaran. Dalam pembelajaran terdapat tahapan sebagai konsep belajar mengajar. Guru sebagai pendidik perlu menyeimbangkan learning system dan teaching system yang secara umum terdapat dalam strategi pembelajaran. Berikut ini tiga pokok tahapan strategi pembelajaran.

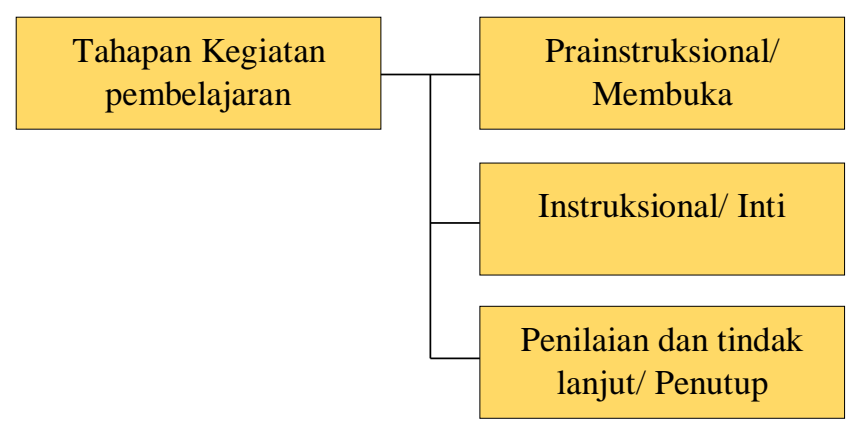


Ketiga serangkaian kegiatan pada tahapan pembelajaran tersebut, guru mengawali dengan tahapan pra-instruksional. Dalam tahapan ini guru mengemukakan tujuan belajar dan hal-hal yang harus dicapai oleh siswa. Selain itu, guru mengaharapkan siswa siap belajar dengan psikis dan fisik. Guru membangun kepercayaan kepada siswa melalui komunikasi atau interaksi yang dibangun guna memudahkan siswa menerima materi belajar dengan baik. Dalam hal ini, posisi kekuasaan guru dapat berubah sesuai dengan peran dan konteks.

2. Hegemonial

Hegemoni sebagai strategi yang dilakukan guru kepada siswa yang mempunyai daya persuasif. Daya persuasif guru tentunya menghadapkan siswa pada posisi siswa bawah yang patuh terhadap perintah yang disampaikan oleh guru. Hegemoni guru dalam membuka pembelajaran, tentunya memberikan ajakan siswa untuk siap belajar secara mental dan psikis. Dengan demikian, siswa harus mampu mencapai tujuantujuan belajar sesuai dengan perintah guru. Berikut kutipan strategi hegemoni guru dalam membuka pembelajaran.

\section{Kutipan (3)}

(Konteks: Tuturan tersebut terjadi di ruang kelas pada pagi hari. Guru (penutur) memerintah siswa (mitra tutur) mendengarkan pembacaan ayat suci al-quran yang dipandu oleh moderator. Guru mengajak siswa mengingat kembali materi sebelumnya dengan sebuah pertanyanpertanyaan)

\section{G: "Dengarkan dahulu, hayo dengarkan orang yang membaca al-quran!"}

$\mathrm{S}$ : siswa mendengarkan bacaan ayat suci alquran.

G: "Baik anak-anak, kita ulas materi kemarin. Kira-kira dari materi yang ibu sampaikan kemarin, kalian masih ingat apa tidak?"

\section{S: (siswa diam sambil mencoba mengingat materi kemarin} yang telah disampaikan oleh guru)

G: "Ayo, kalian ingat-ingat lagi!"

S: siswa diam dan mencoba mengingat kembali.

G: "Coba, kalian beri contoh cerita yang dapat dilisankan"

S: "Kayak (seperti) cerita nano bu!"

(G.1/S.MB/HGM)

\section{Kutipan (4)}

(Konteks: Tuturan tersebut terjadi di ruang kelas pada pagi hari. Guru memerintah siswa membuka buku paket dan mempelajari teks eksposisi) 


\section{G: Sekarang kalian buka buku paket kalian!}

S: siswa membuka buku paket.

G: Hari ini kita akan mempelajari teks Eksposisi.

S: siswa mendengarkan penyampaian instruksi dari guru.

(G.2/S.MB/HGM)

\section{Kutipan (5)}

(Konteks:Tuturan tersebut terjadi di ruang kelas pada siang hari. Guru (penutur) memberikan penjelasan dan pertanyaan kepada siswa terkait dengan materi yang dipelajari yaitu puisi rakyat)

G: "Perlu kalian ketahui, bahwa cerita fiksi itu bersifat tidak nyata. Contoh cerita fiksi yaitu kancil mencuri mentimun. Dalam kehidupan nyata kira-kira kalian pernah melihat apa tidak kalau kancil mencuri mentimun?"

S: "Tidak, bu."

G: "Nah, itu anak-anak salah satu contoh cerita fiksi atau cerita tidak nyata." Bisa diapahami anak-anak?"

S: "Bisa, bu"."

G: "Baiklah, anak-anak kita lanjutkan saja ya materi kita."

\section{(G.3/S.MB/HGM}

Pada kutipan (4) dan (5) merupakan strategi tuturan hegemoni. Dalam percakapan tersebut guru menghegemoni siswa atas otoritas kekuasaan yang dimilikinya. Siswa hanya mengikuti tindakan yang bersifat persuasif dalam materi yang diperintahkan oleh guru. Hal ini hegemoni yang dilakukan guru siswa tunduk terhadap aturan ataupun ucapan guru yang dapat ditandai dengan kekuasaan berupa kata "tidak bu”, “iya bu”, "sudah bu”, dan sebagainya.

Strategi hegemonial memiliki dua titik sudut pandang dalam melihat mekanisme kekuasaan. Mekanisme strategi hegemoni dapat dilihat secara bottom up dan top down. Hegemoni melihat sebuah pemrosesan yang bertindak memberikan daya pengaruh terhadap pihak-pihak yang terdominasi dengan kepemimpinan yang intelektual. Oleh karena itu, pemahaman dan ketidakkonsistenan sebagai mayoritas praktik sosial (Thomas, 2009:373). Nilai dari sistem yang berbeda pemikiran dapat digabungkan ke dalam kerangka ideologis yang lebih koheren. Melalui tatanan sosial tertentu, menjadi umum akal menyatukan kelompok sosial dan memungkinkan hegemoni beroperasi.

Hegemoni dapat terjadi dalam proses pembelajaran. Dalam proses pembelajaran terdapat nilai-nilai dan gagasan yang diterima secara luas, dipegang teguh, disebarkan oleh kelompok-kelompok sosial hegemonik yang membentuk cara- 
cara pemahaman orang dalam periode dan tempat, serta dan sebuah pandangan tertentu. Guru dianggap sebagai seorang yang memiliki kuasa penuh dan dapat menghegemoni siswa secara ideologi bahkan sesuatu tersebut dianggap sebagai sesuatu yang wajar bagi pihak yang didominasi (siswa). Hegemoni berasal dari pengalaman praktis dan kolektif dari realitas sosial yang didasarkan pada akal sehat, akal sehat bukan tentang menggantikan cara pandang berpikir yang ada tetapi tentang menantang atau melihat suatu kegiatan yang sudah ada (Gramsci, 1971:330).

\section{Ekspansif}

Strategi membuka pembelajaran yang dilakukan oleh guru memiliki kaitan erat dengan adanya dorongan atau desakan guru kepada siswa untuk belajar lebih aktif. Dengan hal ini maksudkan guru menciptakan suasana yang dapat memberikan ruang siswa bertanya atau mengemukakan gagasan dalam pembelajaran yang aktif, kreatif, inovatif, kreatif, efektif, dan menyenangkan. Selain itu, dalam kegiatan ini guru mengemukakan tujuan belajar yang disesuaikan dengan kompetensi dasar.

\section{Kutipan (6)}

(Konteks: Tuturan tersebut terjadi di ruang kelas pada pagi har. Sebelum guru memulai pembelajaran, guru mengemukakan tujuan pembelajaran dengan $K D$ )

\section{G: "Kita tinggalkan dulu materi kemarain. Anak-anak hari ini kita akan membahas}

KD teks fantasi. Kira-kira ada yang tahu apa yang dimaksud dengan teks fantasi? Ada yang pernah mendengar cerita fantasi itu seperti apa dan bagaimana?"

S: "Cerita lucu bu"

G: "Kalau cerita lucu itu namanya cerita humor atau komedi. Kalau cerita

fantasi

kira-kira yang bagaimana?"

S: "Cerita khayalan bu"

G: "Sekarang dengarkan penjelasan ibu nak!"

S: siswa diam sambil mendengarkan perintah guru.

G: "Lebih tepatnya cerita fantasi adalah karangan atau tulisan untuk menuturkan, menggambarkan, atau membayangkan berbagai perbuaan, pengalaman, dan kejadian berupa angan-angan, khayalan, imajinasi, atau rekaan belaka.

S: (siswa mendengarkan dengan saksama penjelasan yang disampaikan oleh guru) 
Pada kutipan (6) merupakan strategi guru dalam membuka pembelajaran. Guru mengawali dengan ucapan salam yang dilanjutkan dengan pertanyaan-pertanyaan yang ditujukan kepada siswa. Guru membangun strategi ekspansif dengan suasana pembelajaran yang menyenangkan dan menuntut siswa aktif dengan pertanyaanpertanyaan yang bersifat menggali. Hal demikian dilakukan guru dengan pertanyaan menggali yang mengandung unsur dorongan kepada siswa agar mampu meningkatkan kualitas dan kuantitas jawaban dalam proses pembelajaran. Pertanyaan yang bersifat desakan tersebut dilakukan diawal pembelajaran sebagai menstimulasi kecerdasan berpikir siswa.

Strategi ekspansif mempunyai fungsi bahwa siswa berada dibawah kekuasaan guru sebagai pemegang kendali dalam kegiatan pembelajaran di kelas. Desakan guru terhadap siswa dalam pembelajaran sebagai pertahanan guru dalam memerintah siswa aktif dalam pembelajaran. Oleh sebab itu, guru menggunakan pola interaksi yang bervariasi agar manarik perhatian siswa yang dapat dilakukan tanya jawab dengan siswa terkait materi yang akan dipelajari, membangun keantusiasan siswa, menimbulkan rasa ingin tahu dan sebagainya.

\section{SIMPULAN}

Strategi pembelajaran beriorientasi sebagai standar prosesyang memiliki unsur tersendiri yang dapat membedakan antara kegiatan belajar dengan yang bukan belajar. Unsurunsur tersebut mencakup tujuan belajar, motivasi, hambatan, stimulus, persepsi, dan respon siswa terhadap proses belajar. Strategi resiprokal yang dilakukan oleh guru dalam pembelajaran memiliki peran penting dalam membimbing dan melancarkan siswa menguasai materi ajar. Peran tersebut tentunya melibatkan guru dalam interaksi kelas yaitu membantu dalam mentransformasikan kepercayaan, pengetahuan, pemahaman, keterampilan, dan komitmen kepada siswa. Refleksi dan keyakinan tentang praktik sosial dipandang sebagai cara untuk meningkatkan pemikiran dan pemecahan masalah. Strategi hegemonial memiliki dua titik sudut pandang dalam melihat mekanisme kekuasaan. Mekanisme strategi hegemoni dapat dilihat secara bottom up dan top down. Hegemoni melihat sebuah pemrosesan yang bertindak memberikan daya pengaruh terhadap pihak-pihak yang terdominasi dengan kepemimpinan yang intelektual. Strategi ekspansif mempunyai fungsi bahwa siswa berada dibawah kekuasaan guru sebagai pemegang kendali dalam kegiatan pembelajaran di kelas. Desakan guru terhadap siswa dalam pembelajaran sebagai pertahanan guru dalam memerintah siswa aktif dalam pembelajaran. 


\section{DAFTAR PUSTAKA}

Alexander, R. J. 2017a. Towards Dialogic Teaching: Rethinking Classroom Talk (5th ed.). York, UK: Dialogos. Algesindo.

Bogdan, R. C. danBiklen S. K. 2003. Qualitative Research For Education: An Introduction To Theory And Methods. Boston: Ally and Bacon.

Majid, A. 2012. PerencanaanPembelajaran. Bandung: RosdaKarya.

Hikmah, siti nur afifatul. (2021). Jurnal PENEROKA Vol. 1, No. 01 (2021): Januari 2021. $1(01), 59-67$.

Moh. Syamsul Ma'arif, S. Q. R. (2021). Jurnal PENEROKA Vol. 1, No. 01 (2021): Januari 2021. 1(01), 151-170.

Thomas, P. 2009. The Gramscian moment: Philosophy, hegemony and Marxism (Vol. 24) Leiden: Brill.

Verhaar, J.M.W. 1996. Asas-AsasLinguistikUmum. Yogyakarta: GadjahMada University Press. 